\title{
Correction to: Central Giant Cell Granuloma Treated with Intralesional Corticosteroid Injections and Bisphosphonates: A Long-Term Follow-Up Case Study
}

\author{
Raíssa Pinheiro de Mendonça ${ }^{1}$. Geovanni Pereira Mitre ${ }^{2}$. Flavio Henrique Real ${ }^{3}$. Maria Sueli da Silva Kataoka ${ }^{2}$ \\ Sérgio de Melo Alves Júnior ${ }^{2}$ - Paulo Vianna ${ }^{4}$ Newton Guerreiro Da Silva Júnior ${ }^{3}$ · João de Jesus Viana Pinheiro ${ }^{2,5}$
}

Published online: 14 July 2021

(c) Springer Science+Business Media, LLC, part of Springer Nature 2021

\section{Correction to: Head and Neck Pathology (2020) 14:497-502 https://doi.org/10.1007/s12105-019-01053-x}

After the publication of this article [1] it was brought to the authors' attention that the appropriate consent statement was not included in the manuscript. The correct statement is given below:

Written informed consent was obtained for publication of this case report and any accompanying images. A copy of the written consent is available for review by the Editor-in-Chief.

\section{Reference}

1. de Mendonça Pinheiro, et al. Central giant cell granuloma treated with intralesional corticosteroid injections and bisphosphonates: a long-term follow-up case study. Head Neck Pathol. 2019;14:2. https://doi.org/10.1007/s12105-019-01053-x.

The original article can be found online at https://doi.org/10.1007/ s12105-019-01053-x.

João de Jesus Viana Pinheiro

radface@hotmail.com; joaopinheiro@ufpa.br

Raíssa Pinheiro de Mendonça

raissa.rpm@hotmail.com

Geovanni Pereira Mitre geovannimitre@gmail.com

Flavio Henrique Real flavio.real@hotmail.com

Maria Sueli da Silva Kataoka sukataoka@yahoo.com.br

Sérgio de Melo Alves Júnior sergiomalves@gmail.com

Newton Guerreiro Da Silva Júnior ngsj47@gmail.com
Publisher's Note Springer Nature remains neutral with regard to jurisdictional claims in published maps and institutional affiliations.
1 Department of Oral Pathology, School of Dentistry, Federal University of Ceara, Rua Monsenhor Furtado, Fortaleza, Ceara 60430-355, Brazil

2 Department of Oral Pathology, School of Dentistry, Federal University of Para, Avenida Augusto Correa, 01, Belem, Para 66075-110, Brazil

3 Department of Oral and Maxillofacial Surgery, School of Dentistry, Federal University of Para, Avenida Augusto Correa, Avenida Augusto Correa, 01, Belem, Para 66075-110, Brazil

4 Belem, Brazil

5 Cell Culture Laboratory, Department of Oral Pathology, School of Dentistry, Federal University of Para, UFPA - Institute of Health Sciences, Avenida Augusto Correa, 01, Belem, Para 66075-110, Brazil 